\title{
Effect of using fresh palm oil and used palm oil as a fatliquoring agent to the physical quality of tilapia fish skin in vegetable tannery
}

\author{
Ambar Pertiwiningrum ${ }^{1 *}$, Kurniawan Eko Nugroho $^{1}$, Muhammad Aziz Nur Roufi ${ }^{1}$, Viagian \\ Pastawan $^{1}$, Ragil Yuliatmo ${ }^{2}$, Mohammad Zainal Abidin ${ }^{1}$, and Yuny Erwanto ${ }^{1}$ \\ ${ }^{1}$ Faculty of Animal Science, Universitas Gadjah Mada, Yogyakarta 55281, Indonesia \\ ${ }^{2}$ Department of Leather Processing Technology, Politeknik ATK Yogyakarta, Yogyakarta 55185, \\ Indonesia
}

\begin{abstract}
Fish skin is one of the alternative materials to replace the common animal skin that used in the leather tannery. This research was carried out by vegetable tanning to the tilapia fish skin using selected concentration of fresh palm oil and used palm oil. The study aims to find out the physical quality of leather through the using of fresh and used palm oil as fatliquoring agent in the vegetable tannery process. The same concentration of fresh palm oil $(5 \%)$ and used palm oil $(5 \%)$ were used in this study. The parameter of tensile strength, elongation, and shrinkage temperature as physical quality was observed in triplicates. Based on the results, tensile strength and leather elongation were significantly increased, while the shrinkage temperature was not significantly affected. In conclusion, the addition of palm oil caused the increasing tilapia fish skin quality that can be used for commercial products, and it became the alternative material that could be use in vegetable tannery processing.
\end{abstract}

\section{Introduction}

Tilapia is a type of freshwater fish consumption and is sold as a fresh fish. There are several companies that process tilapia into fillets, and by-product of processing tilapia into fillets is skin. Tilapia skin can have high economic value in the form of tanned tilapia skin [1]. One of the factors that play an important role in the tanning process is the using of tanning agents. The tanning material has advantages and disadvantages, and the properties of tanning agent affect the physical quality. The quality of skin to be a leather depends on the character of the fresh skin itself, especially for fish skin, tilapia fish skin has a good and unique character to be processed in vegetable tannery compared to common others animal fresh skin (Table 1).

Fat liquoring process is part of the tannery which aims to put the oil molecules in space that exists between the fibres of the skin and can serve as a lubricant. Oil is an important component in the skin that functions as a lubricant for skin tissue in the tanning process to make the skin soft [2]. Oils or fats can change the important properties of the skin, including the skin becomes softer, more supple, stretchy, soft, and has a smoother tattoo surface. Plant

\footnotetext{
*Corresponding author: artiwi@mail.ugm.ac.id
} 
oils are widely used as ingredients for skin oiling because they are affordable and easy to obtain. Some examples of vegetable oils are rubber seed oil, soybean oil, sunflower seed oil and palm oil. Sivakumar et al. [2] have used vegetable oil as a fatliquor for leather application. Wang et al. [3] and Kasmudjiastuti et al. [4] also produced and characterized fatliquoring agent from the vegetable oil such as palm oil. Vegetable oils, animal oils, and fish oils contain triglycerides. Palm oil consists of triglycerides which are esters of glycerol with three fatty acid molecules. The use of palm oil in the tanning process can function as an emulsion stabilizer and a good lubricant to produce a limp leather [5-7].

Table 1. Simply character of tilapia fish skin as a tannery material [8-9]

\begin{tabular}{|l|c|c|}
\hline & Fresh Skin & Tilapia Fish Skin \\
\hline Form & Cleavage & Fish scales \\
\hline Color & As a common animal skin & Various color \\
\hline Appearance & Fresh & Fresh \\
\hline Character & Easily rotten & Easily rotten \\
\hline Section arrangement & Epidermic, hypodermic, cutis & Epidermic, hypodermic, cutis \\
\hline
\end{tabular}

In this study, we investigated the using of fresh palm oil and used palm oil as a fat liquoring agent in the tannery of tilapia skin. The study aims to find out the physical quality of leather through the using of fresh and used palm oil as fatliquoring agent in the vegetable tannery process. The physical quality of tilapia leather was observed and evaluated by examining parameters of tensile strength, elongation, and shrinkage temperature.

\section{Materials and methods}

\subsection{Tannery process of tilapia fish skin}

The study was used 100 pieces of tilapia fish skin in tannery process that was conducted in two treatments of fat liquoring process. The materials used in this study included fresh tilapia skin, water, crystal salt, antiseptic, teepol, lime $\left(\mathrm{Ca}(\mathrm{OH})_{2}\right)$, feliderm bate $\mathrm{PB}$, pancreobat enzymes, degreasing agent, formic acid, ZA, FE, sulfuric acid $\left(\mathrm{H}_{2} \mathrm{SO}_{4}\right)$, mimosa, syntan, napo solution, fresh and used palm oil, wetting agent, ammonia, leveling agent, dyestuf, sulphonated oil, formic acid ( $\mathrm{HCOOH})$, and antifungal.

The fat liquoring process is to make the skin softer, has high elongation, and to defend the skin from being damaged by the affection of water, because the skin, that has processed by the fat liquoring, has very good absorption and repulsion to water molecules. The process of tannery was used the same concentration of fresh palm oil (5\%) and used pam oil (5\%) as fat liquoring agent. Although the common oil material used in fat liquoring proses is lipoderm or paradol as much as $6 \%$. This research replaces the common material using those palm oil as an altenative material that provides the same leather quality. The tanning process was carried out in three stages consisting of pre-tanning, tanning, and finishing. The tilapia tannery process is using vegetable tannery materials those are syntan and mimosa as shown in Figure 1. 
Preparing raw materials (preserve using $600 \%$ water, $30 \%$ salt, and $05 \%$ antiseptic) and Sorting (selecting all of fresh skin)

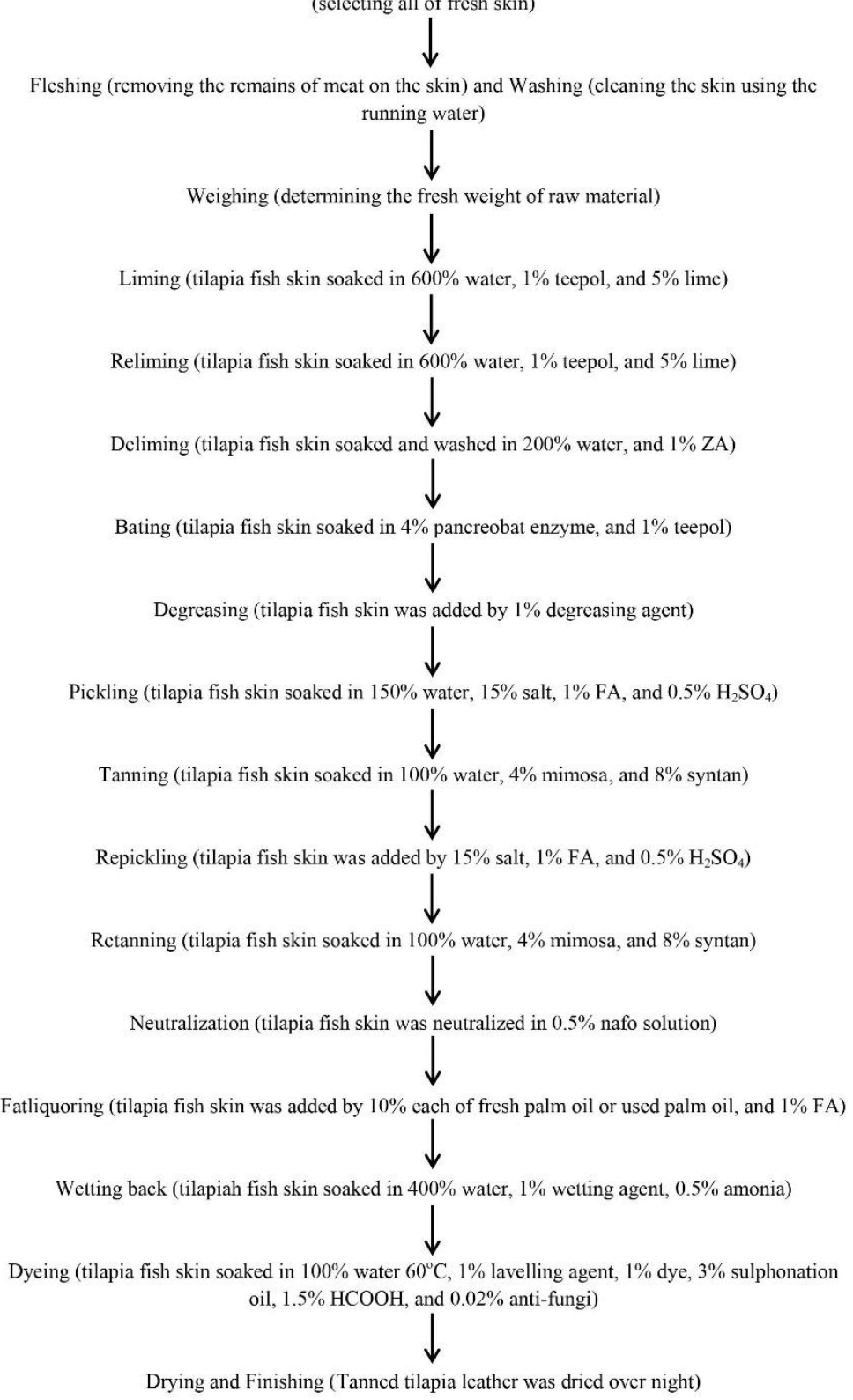

Fig. 1. Vegetable tannery process of tilapia fish skin using palm oil as fat liquoring agent

\subsection{Tensile strength}

Tensile strength is the maximum force required to pull the skin apart. The unit of tensile strength is expressed in $\mathrm{N} / \mathrm{cm} 2$. Tensile strength measurement is carried out using a tool of tensil strength meter. Tensile strength is used as a parameter to determine the magnitude of the bond between the collagen fibers and the tanning material. The tensile strength value can be calculated by the following calculation: 


$$
\text { Tensile strength }=\frac{G}{t x l} \mathrm{~N} / \mathrm{cm}^{2}
$$

$\mathrm{G}=$ maximum tensile load on the sample $(\mathrm{kg})$

$\mathrm{t}=$ sample thickness $(\mathrm{cm})$

$1=$ sample width $(\mathrm{cm})$

Converted into $\mathrm{N} / \mathrm{cm}^{2}(1 \mathrm{~kg}=9.8066 \mathrm{~N})$

\subsection{Elongation}

Elongation is the increase in the length of the leather when the leather is pulled until it breaks divided by the original length. The unit of elongation is expressed in percent (\%). Elongation measurement is carried out using the same tool of tensil strength measurement. Elongation is related to the slackness of the obtained skin. Elongation is one of the physical parameters used in the manufacture of commercial products. The elongation value can be calculated by the following calculation:

$$
\text { Elongation }=\frac{L i-L o}{L o} \times 100 \%
$$

$\mathrm{Li}=$ final length of sample at break $(\mathrm{cm})$

Lo $=$ initial sample length $(\mathrm{cm})$

\subsection{Shrinkage temperature}

Shrinkage temperature is the temperature at which the leather contracts in hot water. The leather sample was cut to a size of $1 \mathrm{x} 4 \mathrm{~cm}$. The measurement of shrinkage temperature is using the tool of shrinkage meter. The sample is attached to the second end of the shrinkage meter clamp. The glycerine solution was put into a glass beaker, then the solution is heated using a stove until it reaches a temperature of $50^{\circ} \mathrm{C}$. The function of glycerine is to increase the boiling point, then the temperature of the solution will increase gradually as it is heated. The thread in the sample that shifts indicates that the sample is shrinking. The shrinkage that occurs is recorded as the shrinkage temperature.

\subsection{Data analysis}

Data on the results of tilapia fish skin tannery using same concentrations of fresh palm oil and used palm oil were analyzed using a T-Test.

\section{Results and discussion}

\subsection{Tensile strength}

We observed the tensile strength of the tilapia leather with the addition of $5 \%$ fresh palm oil and used palm oil. The results of tensile strength measurement with fresh and used palm oil were $3612.9 \mathrm{~N} / \mathrm{cm}^{2}$ and $2709.4 \mathrm{~N} / \mathrm{cm}^{2}$, respectively. The addition of fresh palm oil has a higher result compared to the used palm oil, but the using of those palm oils was not significantly different (Figure 2.a). The standard tensile strength of tilapia leather based on the Indonesian National Standard (SNI) 06-6121-1999 for the upper leather of footwear products is minimum of $1600 \mathrm{~N} / \mathrm{cm}^{2}$, this indicated that the addition of either fresh palm oil 
or used palm oil with the concentration of $5 \%$ is able to provide tensile strength in accordance to SNI for leather upper footwear products.

The more used of palm oil in the fatliquoring process, the more the surface of the leather fibre is lubricated with oil, so that the leather becomes supple and stretch easily. This situation causes the leather fibre bonds to loosen, then the skin's ability to withstand tensile loads decreases [10-11]. Fatliquoring was occurred in two phases, first the oil is taken by the skin mechanically, then followed by an oxidation process. An important binding process is the presence of at least two double bonds in the molecule. In the oxidation process, the double bond takes two oxygen atoms and forms peroxides. Some of the peroxides can react with the amino groups of collagens [12].

The higher concentration of tannery material used in tanning process makes the higher tear strength of the leather. This can occur due to the binding of tannins in mimosa into protein molecules arrange the tilapia skin collagen, that is the amino acids glycine, alanine, and glutamate which results in the formation of cross-links between Gambir tanners and polypeptide chains in the collagen fibres of tilapia skin, which determines the level of strength the physical appearance of the tilapia leather itself. The increasing concentration palm oil as a treatment affected the increase and decrease in the value of tear strength [13]. Concentrations of $5 \%$ palm oil decreased the value of tensile strength due to reduced levels of tannins that entered the skin.

The difference between fresh and used palm oil is that used palm oil has undergone hydrolysis, oxidation, and polymerization. Habib and Alshammari [14] have differentiated the fresh and used (by deep frying) cooking oil. They found increased peroxidation after deep frying with oil. The increasing peroxide value could decrease the emulsifying stability, that can decrease the penetration to the skin. Table 1 shows the lower physical properties (tensile strength, elongation, and shrinkage temperature) of the skin fatliquored with used palm oil compared to the other treatments. It can be caused by low penetration of fatliquoring agent.

a)

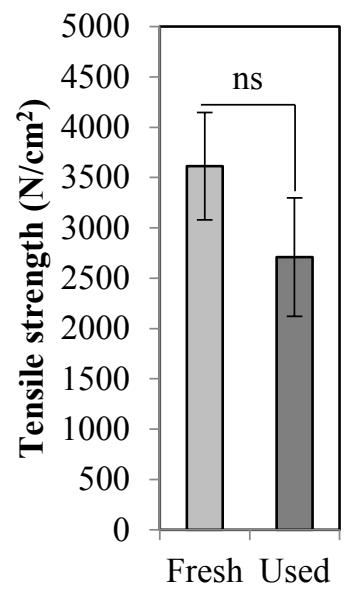

b)

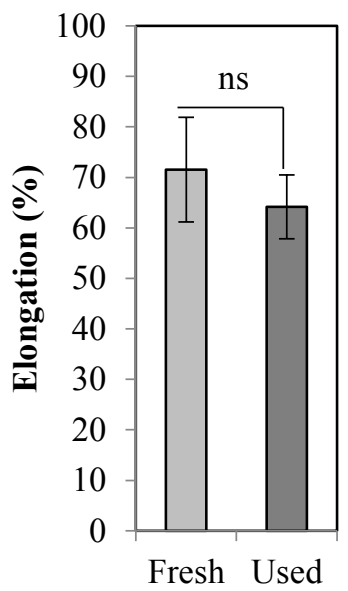

c)

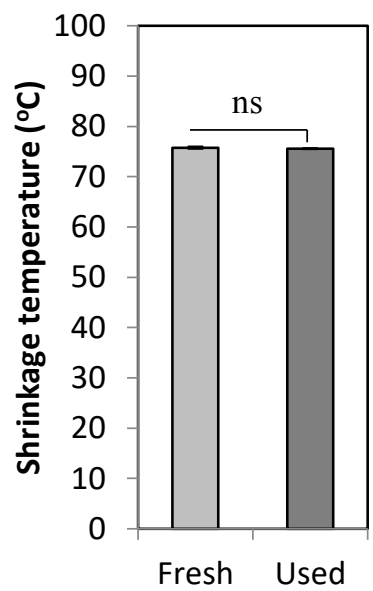

Fig. 2. The physical quality of tilapia leather: a) Tensile strength, b) Elongation, and c) Shrinkage temperature, using $5 \%$ of fresh and used palm oil as fat liquoring agent (Error bars represent standard deviation of mean). *ns: non-significant. 


\subsection{Elongation}

Next, we observed the elongation of the tilapia leather with the addition of $5 \%$ fresh palm oil and used palm oil. The elongation test for tilapia leather with the addition of fresh palm oil and used palm oil was $71.5 \%$ and $64.2 \%$, respectively. The addition of fresh palm oil has a higher elongation value on tilapia leather compared to the used palm oil, but the using of those palm oils was not significantly different (Figure 2.b). The elongation test results from all treatments exceeded the SNI for tanned tilapia skin, which is a minimum of $50 \%$. The number of skin's fibers coated with oil emulsion in low concentration will result in a low leather elongation value. In addition, the elongation of a leather is mainly determined by the amount of oil absorbed by the skin during the fatliquoring stage and also the amount of crosslinking formed between tannery material and collagen. The elongation of the leather will increase when the oil is more absorbed [15-16].

The elongation value with the use of palm oil on the milkfish leather was ranged from $57.23 \%$ to $70.03 \%$, which was smaller than that of synthetic oil $(70.11 \%)$. The high elongation value of the skin is due to the large amount of oil that lubricates the surface of the skin fibers so that the skin becomes more flexible and easily indented [8]. Leather elongation is related to the elasticity, this occurs because there is a reduction of elastin in the calcification process and skin protein erosion. Elastin is a protein that forms very elastic fibers because it has amino acid chains that form angles. The angles become straight when the stress is applied and will return to normal when the stress is released. Loss of elastin in the skin proteins can reduce skin elasticity. The elongation of the skin is also affected by the high protein composition of the fiber. The degree of elongation and slackness is also affected by the finishing process such as toggling, milling, and buffing. The elasticity or looseness of leather is due to the structure of the skin tissue, the process of softening, re-tanning, and fatliquoring [17]. The elongation parameter affects the product quality of the leather goods, such as shoes when they are processed with a machine. If the elongation rate is low, then the leather will be crack, otherwise if the elongation rate is high, then the skin will change shape and increase in size [18]. From the results above, it shows that the tilapia leather that was tanned with syntan and mimosa with the addition of fresh and used palm oil cannot be used to make products that require hard leather materials, because the leather that was produced tends to be limp and stretchy.

\subsection{Shrinkage temperature}

Finally, we observed the shrinkage temperature of the tilapia leather with the addition of 5\% fresh palm oil and used palm oil. The shrinkage temperature measurement for tilapia leather with the addition of fresh palm oil and used palm oil was $75.8 \%$ and $75.6 \%$, respectively. The addition of fresh palm oil has a similar shrinkage temperature value on tilapia leather to the used palm oil, and the using of those palm oils was not significantly different (Figure 2.c). The standard of shrinkage temperature for tanned stingray skin based on the Indonesian National Standard (SNI) 06-6121-1999 for finished goods is at a minimum of $70^{\circ} \mathrm{C}$. The shrinkage temperature test results from all treatments were in accordance with SNI for tilapia leather. This indicates that the concentration of palm oil either fresh or used palm oil showed the enough value to the standard for product.

Leather products with a shrinkage temperature greater than $70^{\circ} \mathrm{C}$ will be more durable because they have higher hydrothermal resistance [18]. This means that tilapia skin tanned with syntan and mimosa with the addition of fresh and used palm oil is the leather that is resistant to heat temperature. In addition, during the tanning process using synthetic tanning agents and mimosa, it will form a hydrogen bonds and covalent bonds are formed between the tannin acids from mimosa and the amino acids that presents in the collagen of the tilapia 
leather. The covalent bonds between collagen and tannins play the most important role in the increasing of shrinkage temperature of the leather. These tannins will form a cross-links with collagen by hydrogen and covalent bonds which produce a leather with a high shrinkage temperature [19].

\section{Conclusion}

It concluded that the addition of palm oil caused the increasing tilapia fish skin quality that can be used for commercial products, and it became the alternative material that could be use in vegetable tannery processing.

This research was funded by The UGM Strategic Research Program, called Final Project Recognition (RTA).

\section{References}

1. A. J. Farid, P. H. Riyadi, U. Amalia, Indones. J. Fish. Sci. Technol. 10, 80-83 (2015)

2. V. Sivakumar, R. P. Prakash, P. G. Rao, B. V. Ramabrahmam, G. Swaminathan, J. Clean. Prod. 16, 549-553 (2008)

3. C. Wang, T. Li, S. Feng, Asian J. Chem. 24, 63-67 (2012)

4. E. Kasmudjiastuti, G. Griyanitasari, D. Rahmawati, Sugihartono, Majalah Kulit, Karet, dan Plastik 34, 19-26 (2018)

5. L. Strijbos, R. Saumweber, M. Hess, C. Gabagnou, J. Fennen, World Leather 20, 19-21 (2012)

6. W. Kassahun, Preparation of Leather Fatliquor Cum Filler from Fleshing Waste for Retanning Process in Leather Manufacture, Master Thesis, Addis Ababa University, Addis Ababa, Ethiopia (2014)

7. A. D. Covington, Tanning Chemistry: The Science of Leather (The Royal Society of Chemistry, Cambridge, UK, 2009)

8. N. Haq, Yunizal, Suherman, Teknologi Pengawetan dan Penyamakan Kulit Ikan (Pusat Penelitian dan Pengembangan Eksplorasi Laut dan Perikanan, Jakarta, Indonesia, 2000)

9. E. Purnomo, Penyamakan Kulit Reptil (Kanisius, Yogyakarta, Indonesia, 2001)

10. P. A. Sitorus, P. H. Riyadi, E. Susanto, Jurnal Ilmu dan Teknologi Perikanan 2, 57-64 (2020)

11. M. Gutterres, L. M. D. Santos, J. Soc. Leather Technol. Chem. 93, 171-175 (2009)

12. R. M. Judoamidjojo, Dasar Teknologi dan Kimia Kulit (Institut Pertanian Bogor, Bogor, Indonesia, 1981)

13. S. Mustakim, A. S. Widati, A. P. Kurniawan, Jurnal Ternak Tropika 11, 38-50 (2010)

14. M. A. Habib, A. G. Alshammari, Indian J. Chem. Technol. 24, 198-205 (2017)

15. D. Nurdiansyah, eJurnal Mahasiswa Universitas Padjadjaran 1, 1599 (2012)

16. R. D. Herhady, R. Sukarsono, in Risalah Seminar Ilmiah Aplikasi Isotop dan Radiasi, 12 December 2006, Jakarta, Indonesia, pp. 67-73 (2006)

17. R. A. Budiyanto, Pengaruh Kadar $\left(\mathrm{Cr}_{2} \mathrm{O}_{3}\right)$ terhadap Mutu Kulit Ikan Kakap (Lutjonus Sp) Tersamak, Undergraduate Thesis, Institut Pertanian Bogor, Bogor, Indonesia (2010)

18. L. Sahubawa, A. Pertiwiningrum, A. T. Pamungkas, Majalah Balai Besar Kulit, Karet, dan Plastik Yogyakarta, 27, 38-45 (2011)

19. O. Suparno, A. D. Covington, C. S. Evans, Teknologi Baru Penyamakan Kulit Ramah Lingkungan: Penyamakan Kombinasi Menggunakan Penyamak Nabati, Naftol dan Oksazolidin (Institut Pertanian Bogor, Bogor, Indonesia, 2012) 